\title{
Estimation of TNF- $\alpha$ Levels in Saliva and Serum of Patients with Periodontal Health and Chronic Periodontitis: A Case-control Study
}

\author{
Kadhiresan Rathinasamy ${ }^{1}$, Arunmozhi Ulaganathan ${ }^{2}$, Shanmugapriya Ramamurthy ${ }^{3}$, Rathinavelu Ganesan ${ }^{4}$, Parthiban Saket ${ }^{5}$, \\ Swarna Alamelu ${ }^{6}$
}

\begin{abstract}
Aim: The aim of this case-control study is to estimate the circulatory levels of tumor necrosis factor alpha (TNF-a) in saliva and serum of patients with chronic periodontitis and periodontally healthy subjects.

Materials and methods: Forty-four patients were screened, and based on biofilm-gingival interface (BGI) index, they were grouped into group I healthy periodontium [BGI-H (20)] and group II periodontitis [BGI-P3 (24)]. Venous blood and salivary samples were collected and analyzed using solid-phase enzyme-linked immunosorbent assay. Independent sample $t$ test was performed to determine the association.

Results: Overall, there were differences in both the saliva and the serum TNF-a levels in healthy and periodontitis subjects. The average serum TNF-a concentration in group I healthy subjects was $23.12 \mathrm{pg} / \mathrm{mL}$ and in group II periodontitis was $24.06 \mathrm{pg} / \mathrm{mL}$. In the saliva, the mean TNF-a level in group I healthy subjects was $45.69 \mathrm{pg} / \mathrm{mL}$ and in group II diseased subjects was $46.58 \mathrm{pg} / \mathrm{mL}$. However, the values were not statistically significant $(p>0.05)$.

Conclusion: Circulatory and salivary TNF-a levels were found in detectable quantities. They showed a marginal increase in chronic periodontitis patients when compared with normal healthy patients in the absence of systemic diseases. Further studies are required in a large scale and with different methodologies to substantiate the role of TNF-a in the progression of periodontal diseases.

Clinical significance: Clinical significance of this study is to analyze the TNF-a levels in saliva and serum, which may be the aggravating factor in causing periodontal disease, thereby helping to treat periodontitis.

Keywords: Chronic periodontitis, Cytokines, Periodontal pockets, Saliva, Serum, Tumor necrosis factor-a.

The Journal of Contemporary Dental Practice (2020): 10.5005/jp-journals-10024-2765
\end{abstract}

\section{INTRODUCTION}

Periodontitis is the major cause of tooth loss in adults after dental caries. The disease is characterized by progressive subgingival bacterial colonization resulting in inflammation, pocket formation, and bone loss. Although periodontal microorganisms are the major cause for periodontitis, the host immune response determines the susceptibility and the outcome of the disease. ${ }^{1}$ As a result of this complex interaction between the periodontopathogens and host tissues, an array of inflammatory mediators such as interleukin-1 (IL-1), interleukin-6 (IL-6), interferon- $\gamma$, and tumor necrosis factor alpha (TNF-a) are released systemically.

These inflammatory mediators are released from infiltrating leukocytes, plasma cells, resident fibroblast, and other connective tissue cells. Tumor necrosis factor alpha, a potent inflammatory mediator, sets up an immune response via the activation of endothelial and gingival fibroblast cells. This leads to the upregulation of the adhesion molecules, matrix metalloproteinase (MMP), and prostaglandin end factor 2. As a result, osteoclastic cells are activated resulting in resorption of bone. ${ }^{2}$ Tumor necrosis factor alpha also inhibits bone formation by the downregulation of osteocalcin gene transcription. The elevated levels of TNF-a lead to an exaggerated immune response causing attachment loss. This may be one of the mechanisms accounting for more severe periodontitis. $^{3}$

In the light of the aforementioned facts, this study has been designed to estimate and compare the TNF-a levels in both saliva and serum of patients with chronic periodontitis and patients with a healthy periodontium.
1-4Department of Periodontology and Oral Implantology, Sri Venkateswara Dental College and Hospital, Chennai, Tamil Nadu, India ${ }^{5}$ Department of Periodontology and Oral Implantology, Adhiparasakthi Dental College and Hospital, Melmaruvathur, Tamil Nadu, India

${ }^{6}$ Department of Periodontology and Oral Implantology, Ragas Dental College, Chennai, Tamil Nadu, India

Corresponding Author: Kadhiresan Rathinasamy, Department of Periodontology and Oral Implantology, Sri Venkateswara Dental College and Hospital, Chennai, Tamil Nadu, India, Phone: +91 9840743339, e-mail: drkadhir@yahoo.com

How to cite this article: Rathinasamy K, Ulaganathan A, Ramamurthy S, et al. Estimation of TNF-a Levels in Saliva and Serum of Patients with Periodontal Health and Chronic Periodontitis: A Case-control Study. J Contemp Dent Pract 2020;21(2):148-151.

Source of support: Nil

Conflict of interest: None

The aim of this study was to compare the TNF-a levels in saliva and serum of patients with chronic periodontitis and patients with a healthy periodontium.

\section{Materials and Methods}

This was designed as a double-blinded randomized analytical study to compare the TNF-a levels in saliva and serum of patients with chronic periodontitis and those with a healthy periodontium. After obtaining the ethical approval from the Institutional Review Board, 
Sree Balaji Dental College and Hospital, Chennai, India, 44 patients (20 males, 24 females, mean age 35) were enrolled for the study.

Patients were grouped according to the biofilm-gingival interface (BGI) classification by Offenbacher et al. ${ }^{4}$ This is one classification which refers more precisely to the activity of inflammation. All teeth present were probed using a UNC-15 probe. Each tooth was examined at six sites (buccal, mesiobuccal, distobuccal, lingual, mesiolingual, and distolingual). Readings were rounded off to the lower whole number.

\section{Group I-20 Subjects}

Healthy periodontium-biofilm-gingival interface-healthy (BGI-H) - subjects with pocket depth (PD) $\leq 3 \mathrm{~mm}$, bleeding on probing $(\mathrm{BOP})<10 \%$.

\section{Group II-24 Subjects}

Periodontitis—biofilm-gingival interface-deep lesion/severe bleeding (BGI-P3) — subjects with PD $\geq 4 \mathrm{~mm}, \mathrm{BOP} \geq 50 \%$.

A written informed consent was obtained from all the subjects after explaining the purpose of the study. Individuals within the age group of 35-55 years having good general and oral health were included in the study. The following exclusion criteria were applied for the selection of the subjects: (1) pregnant individuals, (2) patients with systemic disease, (3) smokers and tobacco chewers, (4) patients with aggressive periodontitis, and (5) history of recent periodontal therapy within the previous 6 months. The study was initiated as a pilot study, and hence, the sample size was limited to 44 .

\section{Sample Collection}

From both the groups of the study population, blood and unstimulated salivary samples were collected.

- Two milliliters of peripheral blood were drawn by venipuncture in 10-mL centrifuge tubes without anticoagulant. The collected sample was centrifuged at $300 \mathrm{rpm}$ for 10 minutes. Sera were separated, frozen, and stored immediately at $-80^{\circ} \mathrm{C}$.

- According to the spitting method of Navazesh, ${ }^{5}$ the subjects were asked to rinse their mouth with water prior to saliva collection and then the saliva was collected in a sterile container. Two hours after a meal, $5 \mathrm{~mL}$ of the whole unstimulated saliva was collected.

Quantification of TNF-a was carried out using the sandwich immunoassay solid-phase enzyme-linked immunosorbent assay kit (Quantikine HS Human TNF-a Immunoassay Kit; R\&D Systems). The reagents and standards were prepared according to the manufacturer guidelines. A $200 \mu \mathrm{L}$ of standard plasma was added to the wells coated with TNF-a-specific monoclonal antibody. After 2 hours of incubation, the wells were washed with a buffered

Table 1: $t$ test for serum tumor necrosis factor- $a$

\begin{tabular}{lllll}
\hline & $n$ & $\begin{array}{l}\text { Mean } \\
(\mathrm{pg} / \mathrm{mL})\end{array}$ & $\begin{array}{l}\text { Standard } \\
\text { deviation }\end{array}$ & $\begin{array}{l}\text { Standard } \\
\text { error }\end{array}$ \\
\hline Group I & 20 & 23.1288 & 7.3757 & 1.8439 \\
Group II & 24 & 24.0600 & 7.0590 & 1.5404 \\
\hline
\end{tabular}

surfactant solution, and anti-TNF-a polyclonal antibody conjugated with alkaline phosphatase was then added. Finally, the wells were washed with nicotinamide-adenine dinucleotide phosphate and prepared with stop solution for reading the optical density at $450 \mathrm{~nm}$. The results for TNF-a were expressed in picograms per microliter.

\section{Statistical Analysis}

The values were expressed as mean \pm standard error of mean. A statistical analysis of variables between the chronic periodontitis and healthy group was carried out using independent sample $t$ test. $t$ test was used to calculate the correlations between serum and salivary TNF-a levels. A value of $p<0.05$ was considered statistically significant. A computer software (SPSS for Windows, release 12.0, Chicago, IL, USA) was used to process the data.

\section{Results}

The mean serum TNF-a level was $23.12 \mathrm{pg} / \mathrm{mL}$ in group I healthy subjects and $24.06 \mathrm{pg} / \mathrm{mL}$ in group II periodontitis (Table 1). On comparison (Table 2 and Fig. 1), these values were not statistically significant $(p>0.05)$. In the saliva, the mean TNF-a level was 45.69 $\mathrm{pg} / \mathrm{mL}$ in group I (healthy) and $46.58 \mathrm{pg} / \mathrm{mL}$ in group II (diseased; Table 3). The computed $p$ value was 0.797 and was not statistically significant (Table 4 and Fig. 2). When the TNF-a levels were compared between serum and saliva in the healthy group and diseased group, there was a marginal increase in the diseased group compared with the healthy group, but they were not statistically significant (Table 5 and Fig. 3). Overall, there was only a negligible difference in the salivary and serum TNF-a levels between group I and group II, which was not statistically significant.

\section{Discussion}

Periodontal pathogens activate a cascade of host inflammatory mediators, thus causing periodontal attachment loss. Among

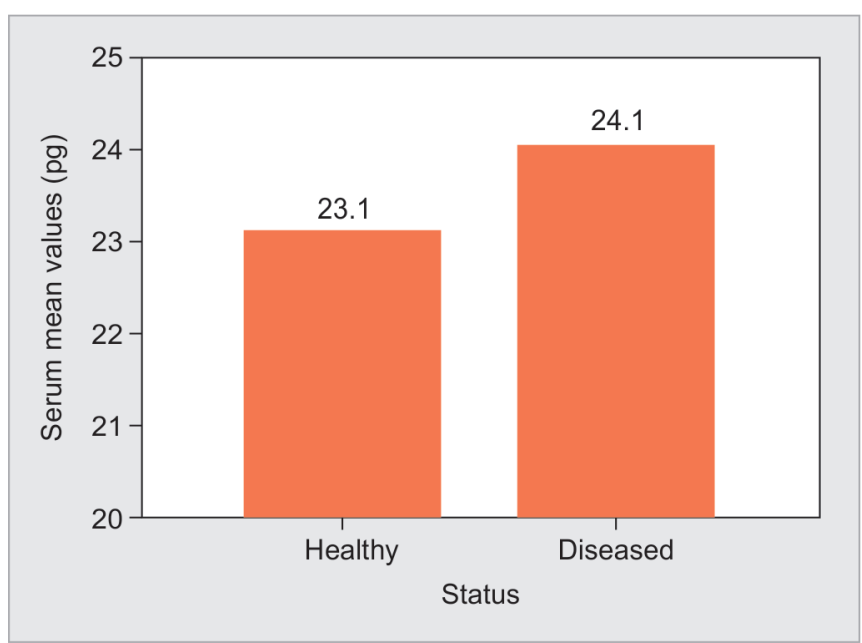

Fig. 1: Comparison of serum tumor necrosis factor-a in group I and group II subjects

Table 2: Independent sample $t$ test for serum tumor necrosis factor- $a$

\begin{tabular}{|c|c|c|c|c|c|c|c|c|}
\hline \multirow[b]{2}{*}{$F$} & \multirow{2}{*}{$\begin{array}{c}\text { Levene's test for equality of } \\
\text { variances }\end{array}$} & \multicolumn{3}{|c|}{$t$ test for equality of means } & \multirow{2}{*}{$\begin{array}{l}\text { Mean } \\
\text { difference }\end{array}$} & \multirow[b]{2}{*}{ Standard error } & \multicolumn{2}{|c|}{ 95\% confidence interval } \\
\hline & & $t$ & $d f$ & Significance & & & Lower & Upper \\
\hline 0.171 & 0.681 & -0.390 & 42 & 0.699 & -0.9312 & 3.4103 & -5.7793 & 3.9168 \\
\hline
\end{tabular}




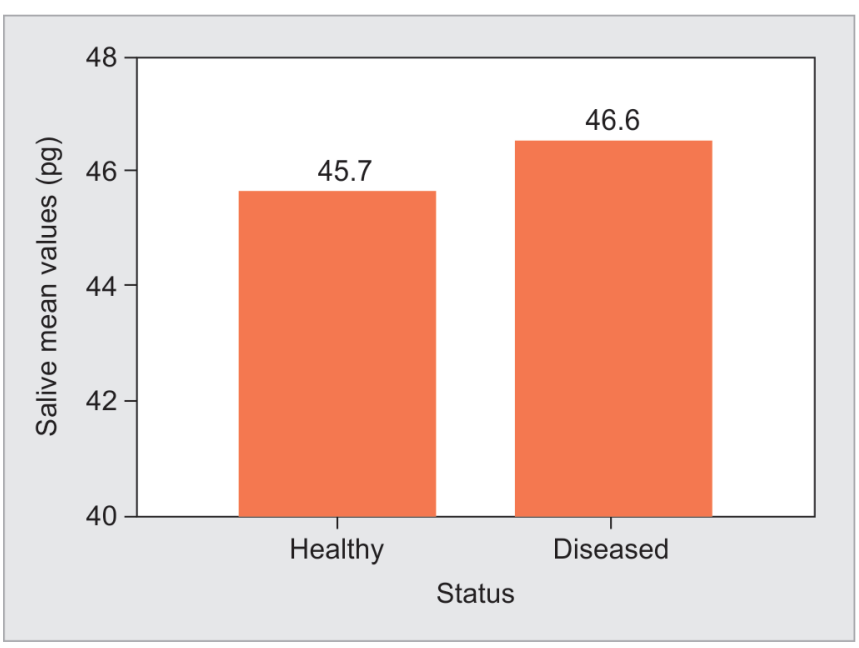

Fig. 2: Comparison of salivary tumor necrosis factor-a in group I and group II subjects

Table 3: $t$ test for salivary tumor necrosis factor- $a$

\begin{tabular}{lllll}
\hline \multicolumn{6}{l}{ Group statistics } & & & \\
& $n$ & $\begin{array}{l}\text { Mean } \\
(\mathrm{pg} / \mathrm{mL})\end{array}$ & $\begin{array}{l}\text { Standard } \\
\text { deviation }\end{array}$ & $\begin{array}{l}\text { Standard } \\
\text { error }\end{array}$ \\
\hline Group I & 20 & 45.6930 & 7.2212 & 2.2836 \\
Group II & 24 & 46.5794 & 9.1229 & 2.2807 \\
\hline
\end{tabular}

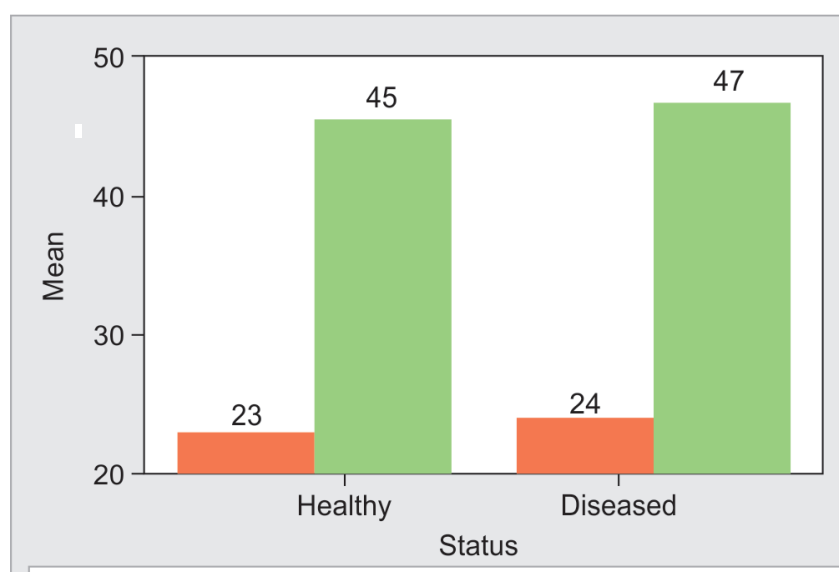

nTNF-alpha serum levels $(\mathrm{pg} / \mathrm{mL})$ — TNF-alpha salivary $(\mathrm{pg} / \mathrm{mL})$

Fig. 3: Comparison of serum tumor necrosis factor-a and salivary tumor necrosis factor-a in group I and group II subjects

Table 5: $t$ test for saliva and serum

\begin{tabular}{lll}
\hline & $\begin{array}{l}\text { TNF-a serum levels } \\
(\mathrm{pg} / \mathrm{mL})\end{array}$ & $\begin{array}{l}\text { TNF-a salivary levels } \\
(\mathrm{pg} / \mathrm{mL})\end{array}$ \\
\hline Group I (mean $\pm \mathrm{SD})$ & $23.12 \pm 7.4$ & $45.69 \pm 2.3$ \\
Group II (mean $\pm \mathrm{SD})$ & $24.06 \pm 7.1$ & $46.58 \pm 2.3$ \\
$p$ value & 0.797 & 0.699 \\
\hline$p$ value $<0.05$ is considered statistically significant
\end{tabular}

Table 4: Independent sample $t$ test for salivary tumor necrosis factor-a

\begin{tabular}{|c|c|c|c|c|c|c|c|c|}
\hline \multirow[b]{2}{*}{$F$} & \multirow{2}{*}{$\begin{array}{c}\text { Levene's test for equality of } \\
\text { variances } \\
\text { Significance }\end{array}$} & \multicolumn{3}{|c|}{$t$ test for equality of means } & \multirow{2}{*}{$\begin{array}{l}\text { Mean } \\
\text { difference }\end{array}$} & \multirow[b]{2}{*}{ Standard error } & \multicolumn{2}{|c|}{$95 \%$ confidence interval } \\
\hline & & $t$ & $d f$ & Significance & & & Lower & Upper \\
\hline 0.564 & 0.460 & -0.260 & 42 & 0.797 & -0.8864 & 3.4103 & -7.9250 & 6.1522 \\
\hline
\end{tabular}

the pro-inflammatory mediators, TNF- $\alpha$ and IL- $1 \beta$ are regarded as the important ones associated with severity of inflammation in periodontitis. ${ }^{6,7}$ Periodontal microbiological studies have observed that Aggregatibacter actinomycetemcomitans and Porphyromonas gingivalis stimulate the monocytes and macrophages to produce TNF-a. Tumor necrosis factor alpha activates osteoclasts and the MMP, resulting in periodontal destruction. ${ }^{8,9}$ Studies on association of TNF-a with periodontitis are not conclusive, but few studies have supported the association of TNF- $a$ and few studies did not find similar observation in causation of periodontitis. There is no concluding report on the etiologic role of this factor to the severity of periodontitis. Therefore, the objective of this study was to compare the TNF-a levels in saliva and serum of patients with chronic periodontitis and those with a healthy periodontium using the BGI classification by Offenbacher et al.

This study was performed as a cross-sectional design. The TNF-a level in saliva and serum of patients with chronic periodontitis and healthy periodontium was estimated and compared. After data analysis, no significant relationship was seen between the presence of TNF- $a$ and generalized moderate chronic periodontitis $(p>0.05)$. These results are in conformity with a previous study by $\mathrm{Ng}$ et al. ${ }^{10}$ In their study, salivary TNF-a was compared between chronic periodontitis and healthy subjects. There was no statistically significant difference in their levels among the groups. But at the same time, another study had observed an increase in salivary TNF- $\alpha$ and IL- 6 in chronic periodontitis patients when compared with healthy individuals. It was concluded that TNF- $a$ and IL-6 may be regarded as diagnostic markers of chronic periodontitis. ${ }^{11}$ This difference in results can be caused by differences in patient selection criteria as we had followed a biofilm interface classification of periodontitis.

In another qualitative and quantitative study, the salivary analysis of IL-1- $\beta$, elastase, lactate dehydrogenase, TNF- $\alpha$, and IL- 6 and the presence of different pathogens in periodontitis subjects were evaluated. Similar to our study, they observed no relationship between periodontitis and inflammatory mediator TNF-a. Regardless of the different sampling techniques, the results were analogs to this study. ${ }^{12}$

A research conducted in the United States involved chronic periodontitis patients within an age range of 17-30 years, and their salivary level of TNF-a was assessed. Here, the periodontitis patients showed a higher level when compared with the control group, and the slight difference in the results was attributed to reasons such as different age groups, limited study samples, and dissimilar sampling and evaluation techniques, ${ }^{13}$ in contrast to the results of the study by $\mathrm{Ng}$ et al., which was also conducted in the United States; ${ }^{10}$ Teles et al. ${ }^{14}$ and Slotwinska and Slotwinski, ${ }^{15}$ which also yielded comparable results similar to that of this study. 


\section{Conclusion}

In this study, patients with generalized chronic periodontitis, which was a common disease, were taken as the study group. Although the results yielded were not statistically significant, a larger study population with rigid inclusion and exclusion criteria and proper subcategorization of the study groups was required to further validate the data and promote the use of TNF- $a$ as serum and salivary biomarkers in predicting the risk of development of systemic disease such as diabetes mellitus.

\section{References}

1. Honda T, Domon H, Okui T, et al. Balance of inflammatory response in stable gingivitis and progressive periodontitis lesions. Clin Exp Immunol 2006;144(1):35-40. DOI: 10.1111/j.1365-2249.2006. 03028.x.

2. Hosokawa Y, Hosokawa I, Ozaki K, et al. Increase of CCL 20 expression by human gingival fibroblasts upon stimulation with cytokines and bacterial endotoxin. Clin Exp Immunol 2005;142(2):285-291. DOI: 10.1111/j.1365-2249.2005.02912.x.

3. Roberts EA, McCaffery KA, Michalek SM. Profile of cytokine mRNA expression in chronic adult periodontitis. J Dent Res 1997;76(12): 1833-1833. DOI: 10.1177/00220345970760120501.

4. Offenbacher S, Barros SP, Singer RE, et al. Periodontal disease at the biofilm-gingival interface. J Periodontol 2007;78(10):1911-1925. DOI: 10.1902/jop.2007.060465.

5. Navazesh M. Methods for collecting saliva. Ann N Y Acad Sci 1993;694:72-77. DOI: 10.1111/j.1749-6632.1993.tb18343.x.
6. Novak K, Novak F. Chronic periodontitis. In: Newman M, Takei $\mathrm{H}$, Klokkevold R, ed. Carranza's Clinical Periodontology, 9th ed., Philadelphia: Saunders; 2006. p. 496.

7. Kjeldsen $M$, Holmstrup $P$, Bendtzen K. Marginal periodontitis and cytokines: a review of the literature. J Periodontol 1993;64(11): 1013-1022. DOI: 10.1902/jop.1993.64.11.1013.

8. Zambon JJ. Periodontal diseases: microbial factors. Ann Periodontol 1996;1(1):879-925. DOI: 10.1902/annals.1996.1.1.879.

9. Socransky SS, Haffajee AD, Cugini MA, et al. Microbial complexes in subgingival plaque. J Clin Periodontol 1998;25(2):134-144. DOI: 10.1111/j.1600-051X.1998.tb02419.x.

10. Ng PY, Donley M, Hausmann E, et al. Candidate salivary biomarkers associated with alveolar bone loss: cross-sectional and in vitro studies. FEMS Immunol Med Microbiol 2007;49(2):252-260. DOI: 10.1111/j.1574-695X.2006.00187.x.

11. Geng W, Ying-Hui T, Sheng-Gen S. Expression of IL-6 and TNF-a activities in saliva of chronic periodontitis patients. Chin J Conserve Dent 2009;5:11.

12. Gursoy UK, Könönen E, Uitto VJ, et al. Salivary interleukin1 beta concentration and the presence of multiple pathogens in periodontitis. J Clin Periodontol 2009;36(11):922-927. DOI: 10.1111/j.1600-051X.2009.01480.x.

13. Rai B. Salivary levels of tumor necrosis factor alpha in periodontitis. Adv Med Dent Sci 2008;2:40-41.

14. Teles RP, Likhari V, Socransky SS, et al. Salivary cytokine levels in subjects with chronic periodontitis and in periodontally healthy individuals: a cross-sectional study. J Periodontal Res 2009;44(3): 411-417. DOI: 10.1111/j.1600-0765.2008.01119.x.

15. Slotwinska SM, Slotwinski R. Saliva levels of interleukin-1 receptor antagonist and soluble receptor type I of tumor necrosis factor in chronic periodontitis. Dent Med Probl 2006;43:15-19. 